Journal of the Geological Society

\title{
Evidence for an early Archaean granite from Bastar craton, India
}

H.M. Rajesh, J. Mukhopadhyay, N.J. Beukes, J. Gutzmer, G.A. Belyanin and R.A. Armstrong

Journal of the Geological Society 2009, v.166; p193-196. doi: 10.1144/0016-76492008-089

$\begin{array}{ll}\begin{array}{l}\text { Email alerting } \\ \text { service }\end{array} & \text { click here to receive free e-mail alerts when new articles cite this article } \\ \begin{array}{l}\text { Permission } \\ \text { request }\end{array} & \text { click here to seek permission to re-use all or part of this article } \\ \begin{array}{l}\text { Subscribe } \\ \text { click here to subscribe to Journal of the Geological Society or the Lyell } \\ \text { Collection }\end{array}\end{array}$

\section{Notes}




\section{S P E C I A L}

Evidence for an early Archaean granite from Bastar craton, India

\author{
H. M. RAJESH${ }^{1 *}$, \\ J. MUKHOPADHYAY ${ }^{1,2}$,
}

N. J. BEUKES ${ }^{1,3}$, J. GUTZMER ${ }^{1}$, G. A. BELYANIN ${ }^{1} \&$

R. A. ARMSTRONG ${ }^{4}$

${ }^{1}$ Palaeoproterozoic Mineralization Research Group,

Department of Geology, University of Johannesburg, Johannesburg 2006, South Africa

${ }^{2}$ Department of Geology, Presidency College, Kolkata 700073, India

${ }^{3}$ Department of Mineralogy, Technische Universität Bergakademie Freiberg, D-09596 Freiberg, Germany

${ }^{4}$ Research School of Earth Sciences, Australian National

University, Canberra, A.C.T. 0200, Australia

*Corresponding author (e-mail: hmrajesh@uj.ac.za)

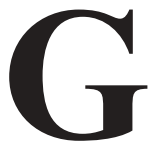

ranitoids in the early Archaean are believed to be potassium-poor tonalite-trondhjemitegranodiorite rocks. Only after continental crust attained sufficient thickness did true (relatively potassium-rich) granites form. No record of true granite prior to $3.4 \mathrm{Ga}$ is available. We report a $3.6 \mathrm{Ga}$ true granite from the Archaean Bastar craton in India. In contrast to the typical early Archaean granitoids, which are commonly deformed into gneisses, this granite is relatively undeformed. The age and composition of the granite implies that continental crust of the Bastar craton attained sufficient thickness to permit intracrustal melting at 3.6 Ga.

Supplementary material: Representative major element, trace element and REE composition of the Dalli-Rajhara granite samples and a summary of SHRIMP U-Pb zircon data for the granite sample D-9 are available at http://www.geolsoc.org.uk/ SUP18337.

The continental crust, covering nearly a third of the Earth's surface, is dominantly made up of granites and granodiorites. An important question in understanding the composition of the continental crust is how the crust has grown with time, especially during the early Archaean, for which the geological record is fragmental. Although there are detrital zircons as old as $4.4 \mathrm{Ga}$ (Wilde et al. 2001), the rocks in which they crystallized remain elusive. Importantly, these zircons are relatively uranium-rich, suggesting that they come from silica-rich rocks typical of true continental crust rather than more mafic rocks. Significant volumes of new crust in the Archaean were associated with the emplacement of felsic rocks of the tonalite-trondhjemite-granodiorite (TTG) series. With an average of c. $70 \mathrm{wt} \% \mathrm{SiO}_{2}$, the TTGs are among the oldest silica-rich igneous rocks on Earth (e.g. the $4.03 \mathrm{Ga}$ Acasta trondhjemite gneiss from Slave craton,
Canada (Bowring \& Williams 1999)) and are different from evolved granitoids in their high $\mathrm{Na}_{2} \mathrm{O}$ and $\mathrm{Al}_{2} \mathrm{O}_{3}$, low $\mathrm{K}_{2} \mathrm{O}$, and steep rare earth element (REE) patterns (Kemp \& Hawkesworth 2003). The appearance of evolved granites is of considerable importance as they are believed to mark a significant change in the crustal behavior, because their emplacement is thought to imply that the continental crust had attained a sufficient thickness for intracrustal melting to occur. Although constituting large areas of all Archaean cratons, evolved granites occur late in the tectonic history of these cratons and typically postdate TTG granitoids (Kemp \& Hawkesworth 2003, and references therein), with no record thus far of a granite (sensu stricto) older than 3.4 $\mathrm{Ga}$ (e.g. $3.4 \mathrm{Ga}$ granite in the Pilbara craton, Australia (Thorpe et al. 1992), 3.1 Ga granite in the Kaapvaal craton, South Africa (Eglington \& Armstrong 2004), 2.7 Ga granite in the Nuuk region, West Greenland (Friend et al. 1996), 2.7 Ga granite in the Kuhmo district, Finland (Käpyaho et al. 2006), and $2.6 \mathrm{Ga}$ granite in the Slave craton, Canada (Davis \& Bleeker 1999)). It should be noted that old TTG complexes, such as the $c .4 \mathrm{Ga}$ Acasta Gneiss Complex, Slave Craton and the 3.8 Ga Itsaq Gneiss Complex, Greenland, have late-stage potassium-rich differentiates, but unlike the granite reported here, these granitic veins are not sufficiently voluminous in any one place to form a pluton. Here we report a true granite of early Archaean age from the Bastar craton, India and interpret its possible tectonic setting. Our discovery of an early Archaean granite has important implications for the nature of plate tectonics in early Earth, as it provides compelling evidence for the existence of thick continental crust prior to $3.5 \mathrm{Ga}$.

Geological setting. The Archaean Dharwar, Bastar, Singhbhum and Aravalli-Bundelkhand cratons (Fig. 1a) form the oldest nuclei of continental crust around which the Indian Peninsula has grown (Radhakrishna \& Naqvi 1986). The plutonic domains of all these cratons have records of $>3.3 \mathrm{Ga}$ old granitic crust, in the form of TTGs. The granite sample for the present study was collected from the Bastar craton, which incidentally also hosts two of the oldest dates from the Indian subcontinent; a $\mathrm{U}-\mathrm{Pb}$ zircon age of $3561 \pm 11 \mathrm{Ma}$ from a tonalite gneiss from the central Bastar craton (Ghosh 2004), and a U-Pb zircon age of $3509 \pm 14 \mathrm{Ma}$ from a trondhjemite gneiss from the southern Bastar craton (Sarkar et al. 1993).

The Bastar craton is a four-sided crustal block that is bounded by two mobile belts, the Central Indian Tectonic Zone to the NW and the Eastern Ghats Belt to the SE, and by two Proterozoic rifts, the Mahanadi rift to the NE and the Godavari rift to the SW (Fig. 1a). A number of other Proterozoic intracratonic basins also formed in the Bastar craton; the most areally extensive is the Chattisgarh basin. The Central Indian Tectonic Zone forms the collision zone along which the South Indian Block (including the Singhbhum, Bastar and Dharwar cratons) and the North Indian Block (including the Bundelkhand craton) amalgamated during the late Archaean (Yedekar et al. 1990). The middle Proterozoic Eastern Ghats Belt is interpreted to be the product of a multistage continent-continent collision involving the South Indian Block and continental crust at present in East Antarctica (Rogers 1996).

Archaean TTG gneisses, relatively undeformed granitoids, metasedimentary or sedimentary supracrustal rocks and mafic dyke swarms constitute the dominant rock types exposed within the Bastar craton (Ramakrishnan 1990). TTG gneisses with abundant metasedimentary enclaves, exposed in large outcrops, constitute the most prominent and ubiquitous rock type of the craton. Granitoid plutons of varying dimensions, forming the 


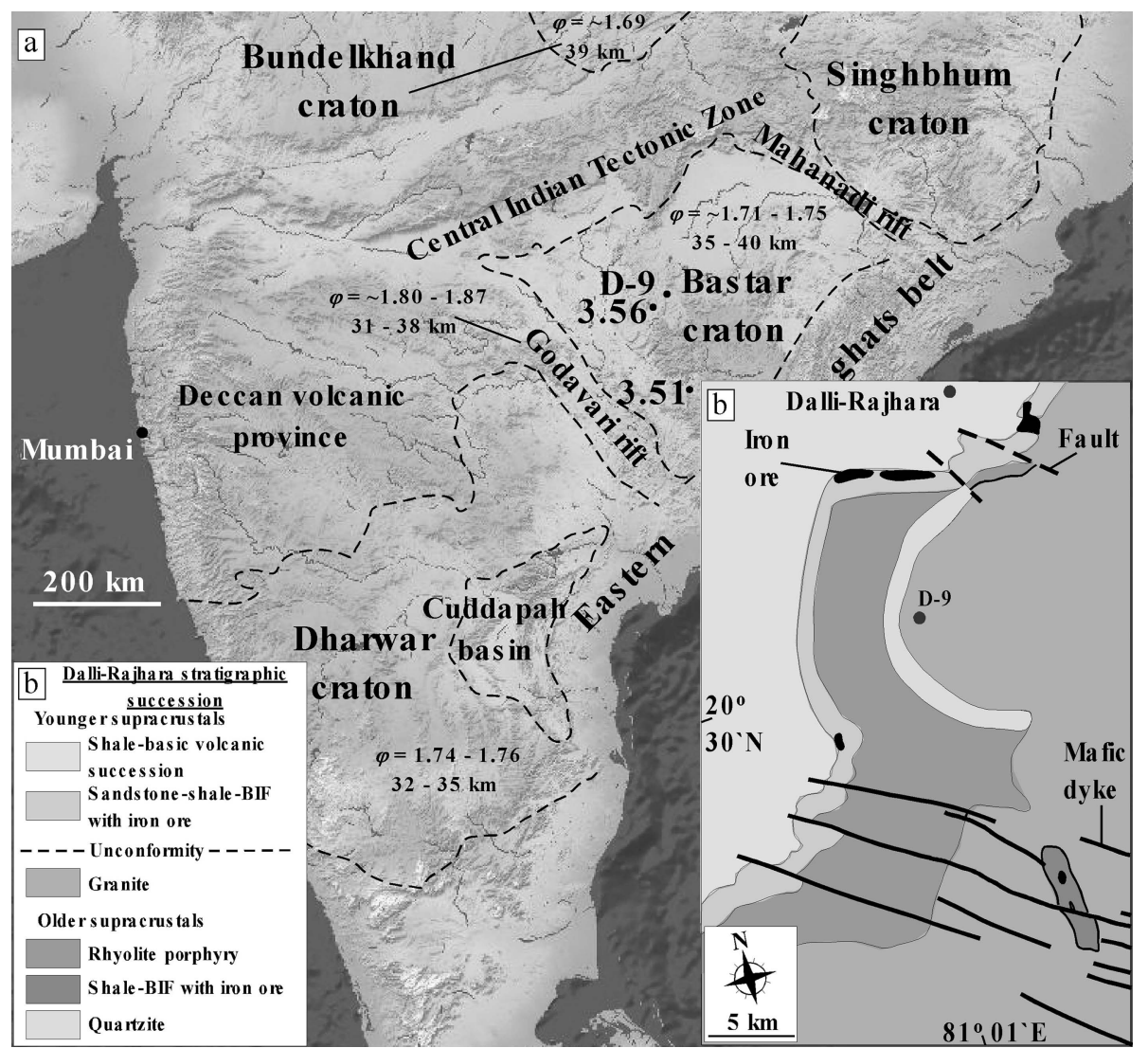

Fig. 1. (a) Shaded relief image showing the location of Bastar and other Archaean cratons in India. The locations of sample D-9, 3.56 Ga tonalite gneiss (Ghosh 2004) and $3.51 \mathrm{Ga}$ trondhjemite gneiss (Sarkar $e t$ al. 1993) from Bastar craton are shown. Compressional wave velocity ratio $\left(V_{\mathrm{p}} / V_{\mathrm{s}}\right.$, expressed as $\varphi$ ) and crustal thickness values (Jagadeesh \& Rai 2007) of the cratons and the Godavari rift are also shown.

(b) Generalized geological map of the area from which the granite sample D-9 was collected. second largest rock unit, occur as intrusive rocks in the gneisses and in the metasupracrustal rocks throughout the craton. Enclaves of gneisses and metasupracrustal rocks abundantly occur within the granitoids, especially in the southern Bastar region. Granitoids with enclaves of banded iron formation (BIF) occur in the central Bastar craton. Two generations of supracrustal rocks occur, with the older Archaean to early Proterozoic generation consisting of folded acid volcanic and siliciclastic rocks, and the younger middle to late Proterozoic generation consisting of undeformed siliciclastic-carbonate successions. High-grade BIFhosted iron ores occur in three distinct BIF-bearing belts: the Dalli-Rajhara belt (part of the present study area; Fig. 1b), the Rowghat belt further south, and the Bailadila belt near the southern end of the Bastar craton. The mafic dyke swarms cut across the older rocks in predominantly NW-SE to WNW-ESE directions and consist of three generations: older amphibolites, younger dolerites and a suite of high-Mg boninite dykes. Most mafic dykes in the southern Bastar craton are parallel or subparallel to the NW-SE-trending Godavari rift and to spatially associated NW-SE-trending lineaments identifiable in satellite imagery.

Characteristics of the granite. The granite reported here is exposed in the central Bastar craton (Fig. 1b). It is pink in colour, massive, unfoliated, medium- to coarse-grained, and dominantly composed of quartz, K-feldspar, plagioclase, hornblende and biotite with subordinate amounts of magnetite, ilmenite, allanite and other accessory minerals (Fig. 2a). Both hornblende and biotite are often altered to chlorite (Fig. 2b). A BIF-bearing supracrustal succession unconformably overlies the granite (Fig. 1b). A representative sample (D-9), collected from an outcrop $\left(20^{\circ} 30.832^{\prime} \mathrm{N}, 81^{\circ} 01.936^{\prime} \mathrm{E}\right)$, about $10 \mathrm{~km} \mathrm{SW}$ of Dalli-Rajhara (Fig. 1b), is $\mathrm{SiO}_{2}$-rich (c. $78 \mathrm{wt} \%$ ), mildly peraluminous (molar
$\mathrm{Al}_{2} \mathrm{O}_{3} /\left(\mathrm{CaO}+\mathrm{Na}_{2} \mathrm{O}+\mathrm{K}_{2} \mathrm{O}\right)$ c. 1.02$)$, corundum normative, ferroan (in terms of $\mathrm{Fe}_{2} \mathrm{O}_{3} * /\left(\mathrm{Fe}_{2} \mathrm{O}_{3} *+\mathrm{MgO}\right)$ ) and calc-alkalic (in terms of $\mathrm{Na}_{2} \mathrm{O}+\mathrm{K}_{2} \mathrm{O}-\mathrm{CaO}$ ). The sample has a total normative quartz (Qtz), albite (Ab), orthoclase (Or) and anorthite (An) of c. $97 \mathrm{wt} \%$, with low An values (c. $2.9 \mathrm{wt} \%$ ), and falls within the granite field in a normative an-ab-or ternary plot (Barker 1979). The $\mathrm{Rb} / \mathrm{Sr}$ (c. 6.4), $\mathrm{Rb} / \mathrm{Ba}$ (c. 0.18) and $\mathrm{Y} / \mathrm{Nb}$ (c. 1.86) ratios of the sample are high, and the $\mathrm{Sr} / \mathrm{Ba}(c .0 .03)$ ratio is low, typical for crustal granites (Harris \& Inger 1992). The REE pattern of the granite sample is light REE-enriched with a prominent negative Eu anomaly (Fig. 2c), typical of upper crustal granites (Kemp \& Hawkesworth 2003). Here, the negative Eu anomaly is different from the general Archaean upper crustal trend, which tends to have no Eu anomalies (Taylor \& McLennan 1995; Fig. 2c) and supports crustal melting as a possible petrogenetic process.

Methods for zircon data collection. The zircons from the granite sample are euhedral to subhedral, and show a wide range in size up to $360 \mu \mathrm{m}$ in length. As is commonly observed in very old rocks the zircons are deeply coloured and the cathodoluminescence (CL) images are generally dull and dark, and show little in terms of internal structure (Fig. 2d). Many grains, however, do show oscillatory zoning consistent with crystallization from a felsic melt. No rounded grains or older cores were observed.

Heavy mineral fractions from the granite sample were separated at the University of Johannesburg. Zircons were hand-picked under a binocular microscope at the Research School of Earth Sciences (RSES) and mounted in epoxy, together with the RSES reference zircons FC1 and SL13. Photomicrographs in transmitted and reflected light were taken of all zircons and these, together with SEM CL images, were used to decipher the internal 

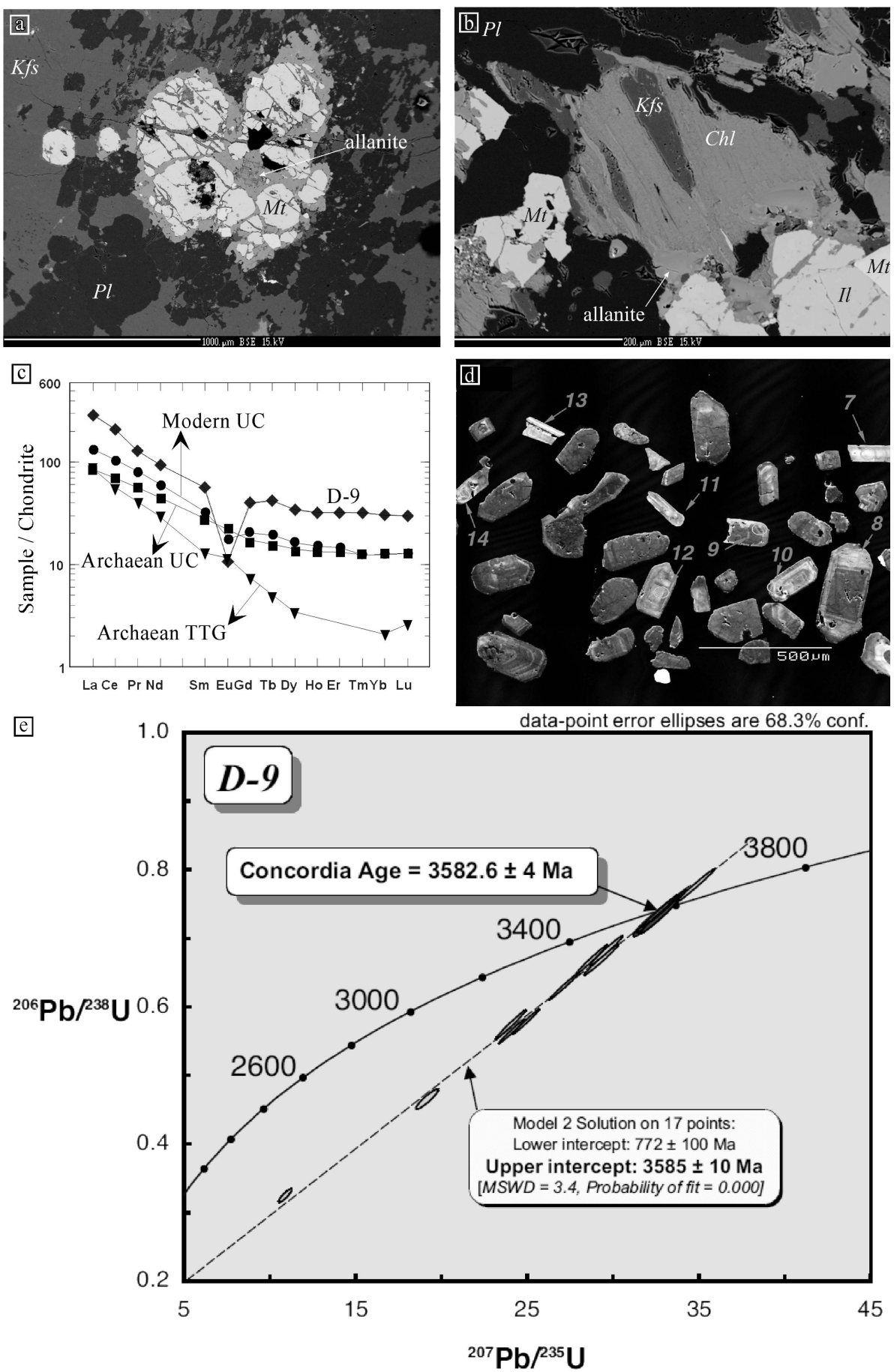

Fig. 2. (a, b) Representative back-scattered electron images illustrating the mineral assemblage of the granite sample D-9. (c) Chondrite-normalized REE distribution pattern of sample D-9 in relation to that of Archaean upper crust (Taylor \& McLennan 1995), modern upper crust (Rudnick \& Gao 2003) and average Archaean TTG (Martin 1994). (d) CL image of zircons from sample D-9. (e) U-Pb concordia plot of all SHRIMP data for zircons from sample D-9. In (d) the numbers correspond to analytical spots and ellipses represent those analyses that were included in the calculation of the concordia age. structures of the sectioned grains and to target specific areas within the zircons for spot analysis (e.g. metamorphic rims).

$\mathrm{U}-\mathrm{Pb}$ analyses were carried out in several sessions using sensitive high-resolution ion microprobe (SHRIMP) I at the RSES. The data have been reduced in a manner similar to that described by Williams (1998), using the SQUID Excel macro of Ludwig (2000). For the zircon calibration the $\mathrm{Pb} / \mathrm{U}$ ratios have been normalized relative to a value of 0.1859 for the ${ }^{206} \mathrm{~Pb} * / 238 \mathrm{U}$ ratio of FC1 reference zircons, equivalent to an age of $1099 \mathrm{Ma}$ (Paces \& Miller 1989). U and Th concentrations were determined relative to the SL13 standard.

Uncertainties given for single analyses (ratios and ages) are at the $1 \sigma$ level; however, uncertainties in the calculated weighted mean ages are reported as $95 \%$ confidence limits (unless stated otherwise) and include the uncertainties in the standard calibrations. Concordia plots, regressions and weighted mean age calculations were carried out using Isoplot/Ex (Ludwig 1999). Concordia ages (Ludwig 1998) were calculated using the SQUID macro (Ludwig 2000) with uncertainties from the standard calibration included in the final errors quoted.

Age of the granite. Eighteen SHRIMP analyses were performed on different grains with spots sited in different areas of zircon grains (rims, centres). The results of the SHRIMP analyses are 
plotted on a Wetherill $\mathrm{U}-\mathrm{Pb}$ concordia plot (Fig. 2e). Some data are concordant and the remainder spread along a discordia trend, with a maximum of $43 \%$ discordance. Regression of all data points yields an upper intercept age of $3585 \pm 10 \mathrm{Ma}$ but with some scatter of the data $(\mathrm{MSWD}=3.4 ; P=0.000)$. The most reliable estimate of the age is obtained from calculation of a concordia age (Ludwig 1998) from the concordant group of zircons. This gives an age of $3582.6 \pm 4 \mathrm{Ma}(n=7$; MSWD $=0.71)$.

Discussion and concluding remarks. The early Archaean age of the granite (interestingly, older than previously published ages of tonalitic and trondhjemitic gneisses from the Bastar craton) indicates that a felsic crustal source existed before 3.6 Ga.

Recent broadband seismic investigations of the northern and central Bastar craton yielded compressional wave velocity ratios $\left(V_{\mathrm{p}} / V_{\mathrm{s}}\right.$, expressed as $\varphi$ ) of $c .1 .71-1.75$, suggestive of felsic crust, and crustal thickness from 35 to $40 \mathrm{~km}$ (Jagadeesh \& Rai 2007). Similar low $\varphi$ values, indicating felsic crust, have been reported beneath the northernmost part of the Indian craton and have been related to the high heat flow and genesis of silicic granites as a result of crustal melting (England et al. 1992; Jagadeesh \& Rai 2007). For comparison, in South Africa, silicic granites occurring in the Limpopo Belt, the collision zone between Archaean Zimbabwe and Kaapvaal cratons, probably account for the low $\varphi$ value (c. 1.73) of the belt and have been used to argue that the crustal section beneath the belt in Archaean time was comparable with the thick crust observed today in the Himalayas (Nguuri et al. 2001). On the other hand, the Archaean Bushveld mafic complex in South Africa has a higher $\varphi$ value (c. 1.78; Nguuri et al. 2001). Clearly, the felsic composition of the crust in central Bastar cannot be explained by arc-related magmatism, as the arc crusts are significantly mafic (yielding higher $\varphi$, usually $>1.78$ ). Thus we relate the early Archaean granite from the Bastar craton to a collisional tectonic setting involving crustal thickening.

As suggested for other well-preserved Archaean cratons (e.g. de Wit 1998), the appearance of potassium-rich granitic rocks reflects thickening and stabilization of the crust, which eventually consolidated the cratonic components into a single entity. On the balance of evidence for a 3.6 Ga undeformed potassium-rich granite in the Archaean Bastar craton and younger potassiumrich granites (Thorpe et al. 1992; Friend et al. 1996; Davis \& Bleeker 1999; Eglington \& Armstrong 2004) in other wellpreserved Archaean cratons, it is suggested that sufficient crustal thickening did take place as early as $3.6 \mathrm{Ga}$ in the Dalli-Rajhara area of the Bastar craton, and that this is arguably one of the earliest known stabilized Archaean cratonic fragments on Earth.

We thank the Dalli-Rajhara Mines, Steel Authority of India Ltd, and the Indian Statistical Institute for field support and hospitality. A. K. Chaudhuri and G. Deb provided valuable field assistance. The National Research Foundation (NRF), South Africa and Department of Science and Technology, India provided financial support as part of the IndoSouth African science exchange programme. C. Hawkesworth, M. van Kranendonk, J. Rogers and R. Srivastava provided valuable and encouraging comments on the manuscript.

\section{References}

BARKER, F. 1979. Trondhjemite: definition, environment and hypotheses of origin. In: BARKeR, F. (ed.) Trondhjemites, Dacites and Related Rocks. Elsevier, Amsterdam, 1-11.

Bowring, S.A. \& Williams, I.S. 1999. Priscoan (4.00-4.03 Ga) orthogneisses from northwestern Canada. Contributions to Mineralogy and Petrology, 134, 3-16.

Davis, W.J. \& Bleeker, W. 1999. Timing of plutonism, deformation, and metamorphism in the Yellow-knife domain, Slave Province, Canada. Canadian Journal of Earth Science, 36, 1169-1187.

DE WIT, M.J. 1998. Archaean granites, greenstones, cratons and tectonics: does the evidence demand a verdict? Precambrian Research, 91, 181-226.

Eglington, B.M. \& Armstrong, R.A. 2004. The Kaapvaal Craton and adjacent orogens, southern Africa: a geochronological database and overview of the geological development of the craton. South African Journal of Geology, 107, $13-32$.

England, P.C., LeFort, P., Molnar, P. \& Pecher, A. 1992. Heat sources for Tertiary metamorphism and anatexis in the Annapuran-Manaslu region, central Nepal. Journal of Geophysical Research, 97, 2107-2128.

Friend, C.R.L., Nutman, A.P., BaAdsgaard, H., Kinny, P.D. \& McGregor, V.R. 1996. Timing of late Archaean terrane assembly, crustal thickening and granite emplacement in the Nuuk region, southern West Greenland. Earth and Planetary Science Letters, 142, 353-365.

Ghosh, J.G. 2004. 3.56 Ga tonalite in the central part of the Bastar craton, India: oldest Indian date. Journal of Asian Earth Sciences, 23, 359-364.

Harris, N.B.W. \& IngER, S. 1992. Trace element modeling of pelite-derived granites. Contributions to Mineralogy and Petrology, 110, 46-56.

JAGADEESH, S. \& RAI, S.S. 2007. Thickness, composition, and evolution of the Indian Precambrian crust inferred from broadband seismological measurements. Precambrian Research, 162, 4-15.

Käpyaho, A., MäNTtÄRI, I. \& Huhma, H. 2006. Growth of Archaean crust in the Kuhmo district, eastern Finland: $\mathrm{U}-\mathrm{Pb}$ and $\mathrm{Sm}-\mathrm{Nd}$ isotope constraints on plutonic rocks. Precambrian Research, 146, 95-119.

Kemp, A.I.S. \& HawkesworTH, C.J. 2003. Granitic perspectives on the generation and secular evolution of the continental crust. In: RUdNick, R.L. (ed.) Treatise in Geochemistry, Vol. 3, The Crust. Elsevier, Amsterdam, 349-410.

LUDWIG, K.R. 1998. On the treatment of concordant uranium-lead ages. Geochimica et Cosmochimica Acta, 62, 665-676.

Ludwig, K.R. 1999. Isoplot/Ex version 2.00: A geochronological toolkit for Microsoft Excel. Berkeley Geochronology Center Special Publications, 1a.

LudwIG, K.R. 2000. SQUID 1.00, A user's manual. Berkeley Geochronology Center Special Publications, 2.

Martin, H. 1994. The Archaean grey gneisses and the genesis of the continental crust. In: Condie, K.C. (ed.) Archaean Crustal Evolution, Developments in Precambrian Geology. Elsevier, Amsterdam, 205-260.

Nguuri, T.K., Gore, J., James, D.E., ET AL. 2001. Crustal structure beneath South Africa and its implication for the formation and evolution of the Kaapvaal and Zimbabwe cratons. Geophysical Research Letters, 28, 2501-2504.

Paces, J.B. \& Miller, J.D. 1989. Precise U-Pb ages of Duluth Complex and related mafic intrusions, northeastern Minnesota: Geochronological insights to physical, petrogenic, paleomagnetic and tectonomagnetic processes associated with the $1.1 \mathrm{Ga}$ mid-continent rift system. Journal of Geophysical Research, 98B, 13997-14013.

Radhakrishna, B.P. \& Naqvi, S.M. 1986. Precambrian continental crust of India and its evolution. Journal of Geology, 94, 145-166.

RAMAKRISHNAN, M. 1990. Crustal development in southern Bastar, central Indian craton. Geological Survey of India Special Publication, 28, 44-66.

Rogers, J.J.W. 1996. A history of continents in the past three billion years. Journal of Geology, 104, 91-107.

RudNick, R.L. \& GAO, S, 2003, Composition of the continental crust. In: Rudnick, R.L. (ed.) Treatise in Geochemistry, Vol. 3, The Crust. Elsevier, Amsterdam, $1-64$.

Sarkar, G., Corfu, F., Paul, D.K., McNaughton, N.J., Gupta, S.N. \& Bishui, P.K. 1993. Early Archaean crust in Bastar craton, central India-a geochemical and isotopic study. Precambrian Research, 62, 127-137.

TAYlor, S.R. \& MCLennan, S.M. 1995. The geochemical evolution of the continental crust. Reviews of Geophysics, 33, 241-265.

Thorpe, R.A., Hickman, A.H., Davis, D.W., Mortensen, J.K. \& Trendall, A.F. 1992. U-Pb zircon geochronology of Archaean felsic units in the Marble Bar region, Pilbara craton, Western Australia. Precambrian Research, 56, 169-189.

Wilde, S.A., Valley, J.W., Peck, W.H. \& Graham, C.M. 2001. Evidence from detrital zircons for the existence of continental crust and oceans on the Earth 4.4 Ga ago. Nature, 409, 175-178.

Williams, I.S. 1998. U-Th-Pb geochronology by ion microprobe. In: McKibBen, M.A., Shanks III, W.C. \& Ridley, W.I. (eds) Applications of Microanalytical Techniques to Understanding Mineralizing Processes. Reviews of Economic Geology, 7, 1-35.

Yedekar, D.B., Jain, S.C., NAIR, K.K.K. \& Dutta, K.K. 1990. The central Indian collision suture. In: Precambrian of Central India. Geological Survey of India Supplementary Publication, 28, 1-43. 